\title{
Impact of precision livestock farming on work and human- animal interactions on dairy farms. A review
}

\author{
Nathalie Hostiou ${ }^{(1)}$, Jocelyn Fagon ${ }^{(2)}$, Sophie Chauvat ${ }^{(3)}$, Amélie Turlot ${ }^{(4)}$, \\ Florence Kling-Eveillard ${ }^{(5)}$, Xavier Boivin ${ }^{(6)}$, Clément Allain ${ }^{(7)}$
}

\footnotetext{
(1) Inra. UMR1273 Territoires. FR-63122 Saint-Genès Champanelle (France).E-mail: nathalie.hostiou@inra.fr

(2) Institut de l'Élevage. Campus INRA. Chemin de Borde Rouge. BP 42118. FR-31321 Castanet-Tolosan (France).

(3) Institut de l’Élevage. SupAgro. 2, Place Pierre Viala. FR-34060 Montpellier (France).

${ }^{(4)}$ Centre wallon de Recherches agronomiques. Département Productions et Filières. Rue de Liroux, 8. BE-5030 Gembloux (Belgique).

(5) Institut de l'Élevage. Maison Nationale des Éleveurs. 149, Rue de Bercy. FR-75000 Paris (France).

(6) Inra. UMR 1213 Herbivores. FR-63122 Saint-Genès Champanelle (France).

(7) Institut de l’Élevage. Lieu-dit Monvoisin. BP 85225. FR-35652 Le Rheu Cedex (France).
}

Received 18 July 2016, accepted 22 May 2017, available online 8 August 2017.

This article is distributed under the terms and conditions of the CC-BY License (http://creativecommons.org/licenses/by/4.0)

Introduction. With increasing herd sizes and decreasing workforce availability, precision livestock farming (PLF) is being developed in the dairy sector to facilitate herd monitoring. A desire to reduce the drudgery of repetitive tasks is another factor contributing to the adoption of PLF. This study, based on a review of the scientific literature, focuses on the impact of PLF on the profession and work organization of dairy farmers.

Literature. Time savings are observed because robots and sensors take on recurrent physical tasks (milking, feeding) while simplifying the monitoring of animals (heat, health problems, etc.). Farmers appreciate the additional flexibility in organizing their work. The information provided can reduce the mental workload due to the anticipation of events (insemination, health problems). However, the mental workload can sometimes be increased due to the complexity of the information involved in managing the multiple alarms or alerts and equipment failures. The relationship between farmers and their animals is also modified.

Conclusions. Precision livestock farming can have a positive impact on dairy farmers' work and can be attractive for young people. However, if the tools are not adapted to farmers' needs and skills, PLF can also lead to negative impacts on farmers and animals. It is therefore critical to consider the different dimensions of farmers' work to facilitate their adoption of these new technologies.

Keywords. Precision agriculture, sensor, robots, automation, labour.

\section{Conséquences de l'élevage de précision sur le travail et les relations homme-animal en élevage laitier (synthèse bibliographique)}

Introduction. L'élevage de précision se développe en élevage laitier pour faciliter la surveillance de troupeaux dans un contexte d'accroissement de la taille des élevages et de diminution de la disponibilité en main-d'œuvre. La réduction de la pénibilité de certaines tâches répétitives est aussi un facteur d'adoption de ces nouvelles technologies. Cette étude, réalisée à partir d'une revue de la littérature scientifique et professionnelle, analyse l'impact de l'élevage de précision sur le métier des éleveurs laitiers et l'organisation de leur travail.

Littérature. Des gains de temps sont observés car les automates et capteurs remplacent les tâches physiques récurrentes (traite, alimentation) tout en simplifiant la surveillance des animaux (chaleurs, problèmes sanitaires, etc.). Les éleveurs apprécient la flexibilité pour organiser leur travail. Les informations fournies peuvent aussi alléger la charge mentale en anticipant des évènements (insémination, problèmes sanitaires). Mais la charge mentale peut parfois être accrue du fait de la complexité des informations à gérer, de la multiplicité des alarmes ou des alertes ou encore des risques de pannes plus fréquents. Les relations entre l'éleveur et ses animaux sont également modifiées.

Conclusions. Les conséquences sur le travail des éleveurs laitiers, si elles comportent des aspects positifs susceptibles d'exercer un attrait pour le métier notamment de jeunes en quête de modernité, peuvent se révéler sources d'échecs si elles ne 
sont pas adaptées aux besoins et aux compétences des éleveurs. Il est donc essentiel de prendre en compte le travail, selon ses différentes dimensions, pour favoriser l'appropriation de ces nouvelles technologies par les éleveurs laitiers.

Mots-clés. Agriculture de précision, capteur, automate, automatisation, travail.

\section{INTRODUCTION}

The emergence of new technologies and their use in animal husbandry, which has given rise to precision livestock farming (PLF), appears to be a possible lever for the sustainable development of livestock farming systems (Berckmans, 2014). Economic factors are not the only factors motivating dairy producers to adopt these new technologies. Economic models have been developed to analyze the value of investing in PLF technologies (Steeneveld et al., 2015), but studies have also shown that although some technologies do not provide economic benefits, they provide opportunities for significant improvements in dairy farmers' quality of life (Dolechek \& Bewley, 2013; Schewe \& Stuart, 2015). For example, several scenarios developed by Jago et al. (2011) showed that while the purchase of automatic estrous cycle detectors can be unprofitable if the detection performance of the equipment is inferior to that of the farmer, the equipment saves $2 \mathrm{~h}$ of work time per day. Indeed, time-saving is often cited as one of the arguments for equipping farms due to an increase in herd size or a reduced labor force (Eastwood et al., 2012; Jago et al., 2013).

However, while a reduced workload is promoted as one of the arguments for adopting precision technologies on dairy farms, much remains unknown about their impact on farmers' work and their profession. Dairy farmers adopt PLF to make their work less arduous and repetitive and to gain more free time. Some farmers are notably attracted to these new technologies and find in them a source of pride and status within their immediate circle (Billon \& Pomiès, 2006). Such technologies are often cited as an advantage, but the impact on the duration and other dimensions of work, such as changes in tasks, the farmer's mental workload, and the human-animal relationship, remains little known.

The objective of this article is to describe the impact of these new technologies on the work and profession of dairy farmers based on a review of the scientific literature, taking into account recent research on the topic (Hostiou et al., 2014a; Hostiou et al., 2014b). Keywords including "sensors", "precision livestock farming", "smart agriculture", "dairy farming" were used with words such as "work", "labour", "labor", "animal welfare", and "workload" to search the relevant literature. Journals from the Web of Science database were used for the period
January 1998 to February 2017 and the proceedings of relevant scientific conferences held between 2000 and 2017 were searched (Proceedings of the European Conference on Precision Livestock Farming, American Conference of Precision Dairy Management and European Conference on Precision Livestock Farming).

\section{DEFINITION AND GENERAL PRINCIPLES OF PRECISION LIVESTOCK FARMING}

While the concept of PLF is quite recent, tools such as individual electronic milk meters for cows began to be developed in the 1970s (Berckmans, 2004; Halachmi \& Guarino, 2016). Different definitions of PLF are given in the literature. Borchers \& Bewley (2015) define it as the use of technologies which enable the measurement of physiological, behavioral, and production indicators in animals with the aim of improving herd management strategies and farm performance. According to Berckmans (2014), PLF is a way of managing a farm through the monitoring and recording of automated, real-time measurements of animal production, breeding, health and well-being. Precision livestock farming has also been defined as the real-time monitoring technologies aimed at managing the smallest manageable production unit's temporal variability, known as "the per animal approach" (Halachmi \& Guarino, 2016). We draw from these various definitions to propose the following: PLF is the coordinated use of sensors to measure behavioral, physiological and production parameters in animals and the characteristics of the farm environment (temperature, hygrometry, ventilation), and of information and communication technologies (ICT) to exchange, store, transform and restore this information to farmers to support decision-making in conjunction with their own observations. Robots which relieve farmers of some daily tasks (milking, feeding) are sometimes coupled with data transfer technologies, and are generally started, adjusted or driven by the sensors which they contain.

According to Aerts et al. (2003), Berckmans (2004), and Whates (2007), several conditions need to be met to enable the continuous monitoring and management of a farm. First, animal-related variables must be measured and analyzed continuously at an appropriate level and frequency with the help 
of sensors. These variables include live weight, ingested food quantity, feeding behavior (ingestion, mastication, rumination, frequency of mouthfuls), and social behavior. Physiological parameters (body temperature and $\mathrm{pH}$, milk composition and physicalchemical characteristics) can also be measured. Second, a reliable predictive model of animals' reactions to environmental conditions (diet, climate, farming practice) must be used. A comparison between what is expected (as calculated by this mathematical model) and the data provided by the sensors identifies animals which have a problem and require the farmer's particular attention. Finally, the predictive model and measurements taken are integrated into an algorithm to help farmers to take their decisions. Real-time environmental controls via alerts sent to farmers (by smart phone, computer) or robots may even be included, for example for fodder distribution or animal sorting. Rutten et al. (2013) described these principles and added an information integration stage taking into account other data (economic, strategic, historical) as well as a decision-making step by the farmer. The accuracy of "precision livestock farming" therefore depends on the quality and reliability of the monitoring of each animal in terms of its physiological and behavioral reactions over time to farm conditions (Meuret et al., 2013).

Different sensors have been developed for dairy production. Many dairy farmers have for a long time used electronic milk meters to precisely measure milk production, pedometers to detect the increased numbers of steps linked to cows in heat, and analyses of milk conductivity to detect mastitis. However, in recent years the equipment available to detect more precisely when cows are in heat, calving, infectious and metabolic disorders, and cows' well-being has expanded considerably (Bewley, 2016; Caja et al., 2016). Sensors have been developed which allow more precise measurements of behavioral parameters (standing/lying down, physical activity in several space dimensions, tail movements, time ruminating). Various milk analysis tools, to identify milk composition (fat, protein, lactose), quality (leukocytes, blood), and the presence of enzymes (lactate dehydrogenase), hormones (progesterone) and ketones (betahydroxybutyrate), are now integrated into new models of milking robots. More recently, sensors used in vivo to measure body temperature (vaginal and ruminal) and ruminal $\mathrm{pH}$ have been proposed for the early detection of calving and infectious and metabolic disorders. Applied to grazing animals, PLF is mainly based on the recording of three parameters: the location, posture and movements of animals with the use of tools to detect jaw movements (jaw switches, pressure sensors, microphones, accelerometers) and to measure grazing intake (Andriamasinoro et al., 2016).

\section{PRECISION LIVESTOCK FARMING: HOW TO BUILD ANOTHER RELATIONSHIP WITH TIME}

\subsection{Saving time}

One reason that dairy farmers opt for PLF, in some cases even before economic considerations, is to improve their productivity and quality of life (de Koning, 2010). Feeding and milking are the most time-consuming activities on dairy farms (Hostiou \& Fagon, 2012). Work organization (who does what and when) varies significantly according to farm size, workforce composition, level of equipment and the farmer's objectives (Hostiou et al., 2014c). While this question is relatively little documented in the literature, some references are appearing in the fields of milking robots, feedstock distribution and, to a far lesser extent, radio frequency identification (RFID). Most authors highlight the time saved by new technologies. In a study carried out in The Netherlands, Rodenburg (2012) report a $29 \%$ time saving on farms equipped with an automatic milking system (AMS). Studies show that AMSs replace human labor in the milking parlor and account for a $30 \%$ reduction in working hours (Heikkila et al., 2010). Some authors report differences of time savings depending on whether the dairy farm is small or large (Pitkäranta \& Rodenburg, 2016). Time savings are also significant in terms of feed distribution. According to Rodenburg (2007), while $7.7 \mathrm{~min}$ per calf per day are needed for individual and manual feeding, only $3.8 \mathrm{~min}$ are required when milk distribution is automated and calves are managed in a group. The time saved can be reinvested in production-related tasks, farm management, or personal activities. Twenty-eight percent of farmers using milking robot confirm that they take more time off on weekends, $83.7 \%$ acknowledge that the time saved makes them more available for their families, and $68.9 \%$ have noticed a better quality of life (Fleuret $\&$ Marlet, 2014). At first glance, it appears logical that the assistance given by PLF contributes to a reduction in daily working time, especially when associated with robots which take the place of the dairy farmer for some tasks (milking, feedstock distribution, animal monitoring). However, new tasks emerge as a result of the introduction of robots and the digitalization of farms, namely the maintenance of the new tools and the analysis of the data generated by these machines. Such operations can, in some cases, reduce the observed time savings (Schewe \& Stuart, 2015).

\subsection{Changing the nature of the work}

The introduction of precision tools brings changes to dairy farmers' work (Désire \& Hostiou, 2015). 
Some tasks emerge related to data consultation, tool management (identification tags, collars, installation of scales) and equipment maintenance and repair (Schewe \& Stuart, 2015). Part of the physical work is replaced by management tasks comprised essentially of checking, often several times a day, information generated by pre-set alerts. The latter indicates equipment malfunctions or animals requiring the farmer's intervention or increased monitoring. On farms equipped with one or more milking robots (Fleuret \& Marlet, 2014), 40 min a day on average are spent in front of the computer. Some daily or regular work tasks such as milking and animal feeding can disappear. The measured parameters provided by new technologies help increase the objectivity of farmers' observations. Finally, some farmers establish new daily tasks (Rodenburg, 2012), such as "pushing" toward the robot cows which have gone too long between milkings. "Managed" movements (a cow must go to the robot to pass from the sleeping to the feeding area) limit the number of cows to "push", while "free" movements increase it.

\subsection{Creating new time relations}

In addition to the time saved, farmers particularly appreciate the additional flexibility in organizing their work because they are able to personalize the schedule of tasks throughout the day and adapt it to their family life (Butler et al., 2012; Schewe \& Stuart, 2015). In the case of AMS, Butler et al. (2012) report that farmers found more flexibility in their labor, but not an overall decrease in labor. The same result was observed on French dairy farms: out of 43 farmers equipped with an AMS, 15 believed they had gained in flexibility but not in working time (Fleuret \& Marlet, 2014). Nevertheless, the introduction of new technologies on a farm sometimes necessitates the reorganization of work since the points of reference evolve. "Nobody knew who was doing what any more" said a Breton farmer who had just installed a milking robot (Fleuret \& Marlet, 2014). With milking no longer structuring each day, the setting of times and tasks becomes more difficult and more dependent on farmers' choices.

\subsection{Farmers' mental health: is precision livestock farming a plus?}

Precision technologies can reduce dairy farmers' mental workload by helping to anticipate physiological or sanitary events which are sometimes hardly visible to the human eye (temperature change, heart rate, etc.). For example, dairy farmers are under less pressure to detect animals that are in heat, or to take the decision to inseminate, due to the use of automated estrous cycle detection equipment (Allain et al., 2016).
However, the use of precision technologies can also increase dairy farmers' mental workload. A considerable amount of information is generated regularly by some sensors, making it difficult to select which information is key for decision-making (Schewe \& Stuart, 2015). The management of alarm warnings is highlighted by farmers as a source of stress, making it essential to establish priorities to decide at what moment to intervene (Hansen, 2015). A study has shown that dairy farmers react to only $3 \%$ of mastitis warnings generated by milking robots (Hogeveen et al., 2013). The management of alerts received by farmers on their phones has been identified as a further stress source. In a study on farms equipped with AMS in France (Désire \& Hostiou, 2015), all farmers felt stress during the time taken to familiarize themselves with the tool, but they learned how to sort the alerts and decide which were the most important (Désire \& Hostiou, 2015). Some said that they remained anxious because they could be called by the computer at any moment.

In a study on the use of an automated estrus detection system for dairy cows (Allain et al., 2016), 17 farmers (out of 20) mentioned that their stress was reduced through the use of the tool. The presence of technological devices on a farm can complicate the replacement of the farmer (for holiday or illness) as it is not always straightforward to find workers to manage these tools. While these new technologies provide help with a diagnosis, they are unable to replace farmers' know-how and experience in identifying animals needing attention (Berckmans, 2014).

\subsection{What relationships between humans, animals and machines?}

New technologies on farms change how farmers work with their animals, either directly by modifying interaction situations (visual, sound and tactile) and monitoring practices, or indirectly by providing farmers with new information on the animals. This is likely to affect farmers' daily experience with, and perception of, their animals, the animals' behavior, the humananimal relationship, and the animals' performance (Hemsworth, 2003).

On the one hand, some technologies run the risk of damaging human-animal relationships. Automation can reduce the number and length of farmer-animal interactions (transition from twice-daily manual milking to robot milking, automatic straw-mulching). The physical distance between farmers and animals is likely to increase. Opportunities to directly observe the animals, their behavior, health and well-being, could be reduced. Such occasions provide opportunities for farmers and animals to get to know one another better. Deprived of them, animals may become more fearful of humans, especially animals with nervous dispositions 
(Boivin et al., 2012), which would tend to reduce their well-being. The proportion of positive to negative interactions could equally be modified. Opportunities for regular positive interactions, such as feeding times, may diminish, along with the bonds that they create. This then may lead to relationships between farmers and animals which are mainly shaped by negative interactions such as vaccinations, castration, and trimming, as these would be the only times that farmers are in direct contact with their animals (Cornou, 2009).

On the other hand, new technologies can lighten farmers' workloads and reduce the need to manhandle animals, for example, when a farmer has to "push" cows into the milking parlour. New situations favoring positive interactions and human-animal contact can occur, such as when farmers with a milking robot need to move frequently and calmly among the herd to check the equipment, or to bring forward cows which have not come to be milked spontaneously. Some farmers use the amount of time saved by PLF to observe and be present with their animals. These new practices can have a beneficial effect on the animals and be a source of satisfaction for the farmers themselves (Fleuret \& Marlet, 2014).

Data supplied by new technologies contribute further to changing how farmers view their animals, providing an individualized, rather than herd-scale, understanding of each one. On the other hand, using the data takes time away from other tasks, and having to sort through the mass of data available can prove to be complicated for farmers. This transformation in the nature of the job carries with it the acquisition of new skills but equally the loss of "traditional" skills, and some farmers may lose their motivation with regard to their profession and relations with animals (Cornou, 2009).

The change for the animals is equally substantial. Experience shows that animals adapt relatively quickly. In the case of milking robots, authors such as Driessen \& Heutinck (2015) describe this technology as giving relative freedom to the animal. The animal can express its own subjectivity in its choices and even participate directly in the work (Porcher \& Schmitt, 2010; Holloway et al., 2014) in what is nevertheless a constrained system where movement circuits are imposed, given that the animal must first pass via the robot if it wants to rest or feed.

Animals and farmers are actively involved in PLF and farmers acquire new skills and routines. Technologies do not necessarily create more distance between humans and animals, but new relationships are created (Lagneaux \& Servais, 2014). To help construct these, training could be provided to farmers to reduce negative interactions, for example by encouraging positive daily contacts such as visits, movements amongst the animals, vocal contact and so on, at appropriate periods, or by encouraging the selection of animals for breeding which have good relationships with humans.

\section{DISCUSSION}

\subsection{Impact on aspects of work which need to be made more tangible}

Although PLF is presented in numerous studies as a lever for reducing dairy farmers' working time, these time savings remain somewhat theoretical, especially as they are only achievable if the farmer spends an equal or even greater time putting the technologies in place. It is even more difficult to estimate time savings on tasks which have not necessarily been benchmarked, or which are not always clearly quantified (monitoring during calving or for estrous detection), as some of these tasks can be done while animals are engaged in other activities (for example, during milking or feeding). Additionally, time spent will probably differ between initial use and later years as farmers learn to master the innovations (Eastwood et al., 2012). De Koning (2010) states that time savings from using milking robots as opposed to a traditional milking practice represent 20 to $30 \%$ of the total time devoted to milking, depending on the farm. Yet a lack of time, particularly for learning how to use the new technologies, is highlighted as a reason for not adopting them (Fountas et al., 2004 ${ }^{1}$ cited by Lawson et al., 2011). This factor is cited irrespective of the size of the farm (Reichardt \& Jurgens, 2009).

The adoption of PLF on a dairy farm leads to a change in the content and nature of tasks, and has, therefore, an impact on different aspects of the work, whether organizational (who does what and when), or sociological (relationship to work, animals, and the profession). Yet scant research has been devoted to examining the details of farmers' physical workloads, skills and profession.

Robots, coupled with sensors, replace the farmer for physically demanding tasks. In dairy farming, the most illustrative case is the milking robot. Rather than engaging in the physical work of milking, farmers assume animal surveillance tasks and manage information provided by the computer (Schewe \& Stuart, 2015). The replacement of the farmer by the machine can reduce the farmer's physical workload. Hansen (2015) showed that farmers with AMS can sleep more, which can have potential health benefits, but this also needs to be explored in more detail. Although equipment manufacturers highlight such

\footnotetext{
${ }^{1}$ Fountas S. et al., 2004. Farmer experience with precision agriculture in Denmark and US Eastern Corn Belt. Precis. Agric., 5, 1-21.
} 
health benefits to sell their technologies to farmers, there is a lack of objective data on the extent to which the sensors reduce accidents and disease and more generally ease workloads.

The transformation of dairy farmers' skills due to the adoption and use of precision livestock tools is also little documented in the literature. As seen previously, the introduction of such tools frequently reduces the time dedicated to some tasks, even eliminating them, while at the same time new tasks are created. The farmer must manage the data collected, organizing data bases, characterizing, sorting and selecting the pertinent information from the mass available, to analyze and cross-check it in order to set sensible alert and intervention thresholds. A three-phase learning trajectory was observed amongst dairy farmers, involving early learning, consolidation, and advanced use. Farmers exhibited experiential learning but also learned via interaction with a network of on- and offfarm contacts, forming a network of practice around the new users (Eastwood et al., 2012). Due to the new tasks required, farmers and other categories of farm workers (partners, associates and salaried workers) must acquire new skills. All or part of the data management work is frequently delegated to private companies, which allows the collected information to be pooled and the analysis refined. Furthermore, the maintenance of these diverse technological devices (robots, sensors, computers) requires skills which until recently did not feature in a livestock farmer's job. The use of new technologies can lead to diminished autonomy in decision-making if farmers place total confidence in the responses given by the algorithms and lose a critical perspective on the data.

The use of precision tools could also modify how farmers view their profession. Authors (Butler et al., 2012; Hansen, 2015; Schewe \& Stuart, 2015) have demonstrated that milking robots give farm work a more modern image, improving how future farmers view the profession and encouraging young farmers to set up farms. However, further research should be carried out to examine technologies other than AMS, and also to collect the points of view of future farmers.

No research has been undertaken to consider the impact of these technologies on society's perception of the farmers using them. The image of farms becoming increasingly industrial may alienate consumers who view this equipment in a negative light.

Research also is needed on the changes in the work and profession of farmers in other animal production sectors (pigs, poultry, sheep, for example) where the social dimension has not been extensively explored. Furthermore, in dairy farming, most references focus on milking robots and do not examine other tools, in small samples of farms, although many are available. The transformation of the work and profession of farmers will certainly not be the same.

\subsection{The costs and benefits of introducing precision livestock farming}

The cost/benefit relationship is one of the principal reasons that farmers do or do not adopt these new technologies (Bewley \& Russell, 2010). However, the calculation of this ratio is not easy since, beyond the technical and economic factors considered, work changes are rarely taken into account. This is because it is extremely difficult to quantify the economic value of the well-being brought to the farmer by new technologies (Otte \& Chilonda, 2000). For example, it is hard to measure the satisfaction derived from having healthy animals, or working in safe conditions, or from improving the farm's environmental impact (Huirne et al., 2003). While other issues, such as improving product quality and environmental impact, need to be considered, it is above all the balance between economic performance and the improvement of quality of life which has to be evaluated when deciding whether or not to make the investment.

The farmer's decision-making role remains essential.

The objective data measured by sensors enable the anticipation of, and even reassurance for, farmers' decisions when these are combined with in situ observation. It is too simplistic to think that a farm can run itself alone thanks to PLF. While PLF can support decision-making, the farmer's know-how remains essential to manage and react (Berckmans, 2014). It is therefore necessary to ensure that these skills do not disappear. The more that farmers master the different aspects of their job, the greater the benefits will be (responsiveness, independence, relevance, etc.). This expertise can apply at the collective level, rather than to an individual (Eastwood et al., 2016).

\section{CONCLUSIONS}

The development of precision livestock farming (PLF) on dairy farms modifies the duration of work, the content and the nature of the tasks carried out by farmers, their mental workload, and the relationship between farmers and their animals. It is therefore essential to take into account farmers' work, and its different dimensions, to facilitate the adoption of these new technologies by farmers. If the tools are not adapted to farmers' skills and needs, the adoption of PLF could have a negative impact on both farmers and animals. A prospective bioethical analysis is also needed, as PLF may be viewed unfavorably by consumers as a technology that encourages the instrumental use of animals, potentially compromising animal welfare. The positive effect of PLF in rendering the profession of farming more attractive also needs to be explored. 


\section{Bibliography}

Aerts J.M., Wathes C.M. \& Berckmans D., 2003. Dynamic data-based modelling of heat production and growth of broiler chickens: development of an integrated management system. Biosyst. Eng., 84, 257-266.

Allain C. et al., 2016. Technical, economic and sociological impacts of an automated estrus detection system for dairy cows. In: Kamphuis C. \& Steeneveld W., eds. Proceedings of the Conference on precision dairyfarming, 21-23 June, 2016, Leeuwarden, The Netherlands. Wageningen, The Netherlands: Wageningen Academic Publishers, 451-456.

Andriamasinoro L.H.A., Bindelle J., Mercatoris B. \& Lebeau F., 2016. A review on the use of sensors to monitor cattle jaw movements and behavior when grazing. Biotechnol. Agron. Soc. Environ., 20, 273286.

Berckmans D., 2004. Automatic monitoring of animal by precision livestock farming. In: Madec F. \& Clement G., eds. Animal production in Europe: the way forward in a changing world. Saint-Malo, France: International Society for Animal Hygiene, 27-31.

Berckmans D., 2014. Precision livestock farming technologies for welfare management in intensive livestock systems? Rev. Sci. Tech., 33, 189-196.

Bewley J.M., 2016. Update on use of sensors on dairy farms. In: Kamphuis C. \& Steeneveld W., eds. Proceedings of the Conference on precision dairy farming, 21-23 June, 2016, Leeuwarden, The Netherlands. Wageningen, The Netherlands: Wageningen Academic Publishers, 4145.

Bewley J.M. \& Russell R.A., 2010. Reasons for slow adoption rates of precision dairy farming technologies: evidence from a producer survey. In: Proceedings of the first North American conference on precision dairy management, Toronto, Canada, 30-31, http:// www.precisiondairy.com/proceedings/s1 bewley2.pdf, (19/05/2017).

Billon P. \& Pomiès D., 2006. Le point sur la robotisation de la traite 15 ans après l'apparition des premiers systèmes dans les fermes. In : Actes des $13^{e}$ Rencontres Recherches Ruminants, décembre 2006, Paris, France. Paris : Inra ; Institut de l'Élevage, 143-150.

Boivin X. et al., 2012. Hommes et animaux d'élevage au travail: vers une approche pluridisciplinaire des pratiques relationnelles. INRA Prod. Anim., 25, 159168.

Borchers M.R. \& Bewley J.M., 2015. An assessment of producer precision dairy farming technology use, prepurchase considerations, and usefulness. J. Dairy Sci., 98, 4198-4205.

Butler D., Holloway L. \& Bear C., 2012. The impact of technological change in dairy farming: robotic milking systems and the changing role of the stockperson. R. Agric. Soc. Engl., 173, 1-6.
Caja G., Castro-Costa A. \& Knight C.H., 2016. Engineering to support wellbeing of dairy animals. J. Dairy Res., $\mathbf{8 3}$, $136-147$

Cornou C., 2009. Automation systems for farm animals: potential impacts on the human-animal relationship and on animal welfare. Antrhozoös, 22, 213-220

De Koning C.J.A.M., 2010. Automatic milking-common practice on dairy farms. In: Proceedings of the First North American Conference on precision dairy management, March 2010, Toronto, Canada, 52-67, http://www. precisiondairy.com/proceedings/s3dekoning.pdf, (10/03/2016).

Désire C.\& Hostiou N., 2015. L'élevage de précision : quels changements dans l'organisation du travail et la gestion de données en élevage? In: Actes des $4^{e}$ Rencontres nationales sur le travail en élevage, 5-6 novembre 2015, Dijon, France. Paris : Inra, 62-63.

Dolechek K. \& Bewley J., 2013. Pre-investment considerations for precision dairy farming technologies, http://www2.ca.uky.edu/agc/pubs/ASC/ASC208/ ASC208.pdf, (30/01/2016)

Driessen C. \& Heutinck L.F.M., 2015. Cows desiring to be milked? Milking robots and the co-evolution of ethics and technology on Dutch dairy farms. Agric. Hum. Values, 32, 3-20.

Eastwood C.R., Chapman D.F. \& Paine M.S., 2012. Networks of practice for co-construction of agricultural decision support systems: case studies of precision dairy farms in Australia. Agric. Syst., 108, 10-18.

Eastwood C.R. et al., 2016. Understanding the roles of farm advisors in precision dairy farming. In: Kamphuis C. \& Steeneveld W., eds. Proceedings of the Conference on precision dairy farming, 21-23 June, 2016, Leeuwarden, The Netherlands. Wageningen, The Netherlands: Wageningen Academic Publishers, 421-426.

Fleuret M. \& Marlet A., 2014. De la salle de traite au robot. Quels impacts ? Terra, 449, 23-29.

Halachmi I. \& Guarino M., 2016. Editorial: precision livestock farming: a 'per animal' approach using advanced monitoring technologies. Animal, 10, 14821483.

Hansen B.J., 2015. Robotic milking-farmer experiences and adoption rate in Jæren, Norway. J. Rural Stud., 41, 109117.

Heikkila A.M., Vanninen L. \& Manninen E., 2010. Economics of small-scale dairy farms having robotic milking. In: Proceedings of the First North American Conference on precision dairy management, March 2010, Toronto, Canada, www.precisiondairy.com/ proceedings/s3heikkila.pdf, (19/05/2017).

Hemsworth P.H., 2003. Human-animal interactions in livestock production. Appl. Anim. Behav. Sci., 81, 185-198.

Hogeveen H., Buma K.J. \& Jorritsma R.， 2013. Use and interpretation of mastitis alerts by farmers. In: Berckmans D. \& Vandermeulen J., eds. Proceedings 
of the $6^{\text {th }}$ European conference on precision livestock farming, Leuven, 10-12 September, 2013, Belgium, 313319.

Holloway L., Bear C. \& Wilkinson K., 2014. Re-capturing bovine life: robot-cow relationships, freedom and control in dairy farming. J. Rural Stud., 33, 131-140.

Hostiou N. \& Fagon F., 2012. Simplification des conduites d'élevage : analyse transversale des pratiques mises en œuvre dans les filières herbivores et granivores. Inra Prod. Anim., 25, 127-140.

Hostiou N. et al., 2014a. Conséquences de l'élevage de précision sur le travail des éleveurs. In : Actes des $21^{e}$ Rencontres Recherches Ruminants, 3-4 décembre 2014, Paris, France. Paris : Inra ; Institut de l'Élevage, 11-14.

Hostiou N. et al., 2014b. L'élevage de précision : quelles conséquences pour le travail des éleveurs ? INRA Prod. Anim., 27, 113-122.

Hostiou N., Chauvat S. \& Cournut S., 2014c. Faire face à des questions de travail : les leviers mobilisés par des éleveurs laitiers. In : Gasselin P., Choisis J.-P., Petit S. \& Purseigle F., eds. L'agriculture en famille : travailler, réinventer, transmettre. Les Ulis, France : EDP Sciences, 125-144.

Huirne R.B.M. et al., 2003. Financing losses of infectious livestock diseases in Europe: an economic risk analysis. In: Geers R. \& Vandenheede J., eds. Proceedings of the $10^{\text {th }}$ Annual meeting of the Flemish Society for Veterinary Epidemiology and Economics \& $15^{\text {th }}$ Annual meeting of the Dutch Society for Veterinary Epidemiology and Economics: risk-assessment and its applications in animal health and food safety, 6 February, 2003, Katholieke Universiteit Leuven, Leuven, Belgium, 65-74.

Jago J., Burke Ch., Dela Rue B. \& Kamphuis C., 2011. Automation of estrus detection. Dairy NZ Technical Series, December 2011, 2-7, https://www.dairynz.co.nz/ media/424967/technical_series_december_2011.pdf, (19/05/2017).

Jago J., Eastwood C., Kerrish K. \& Yule I., 2013. Precision dairy farming in Australasia: adoption, risks and opportunities. Anim. Prod. Sci., 53, 907-916.

Lagneaux S. \& Servais O., 2014. De la traite robotisée au raid d'avatars. Incorporation et virtualisation. Parcours Anthropol., 9, 73-101.

Lawson L.G. et al., 2011. A four nation survey of farm information management and advanced farming systems: a descriptive analysis of survey responses. Comput. Electron. Agric., 77, 7-20
Meuret M., Tichit M. \& Hostiou N., 2013. Élevage et pâturage «de précision »: l'animal sous surveillance électronique. Courrier Environ. Inra, 63, 13-24.

Otte M.J. \& Chilonda P., 2000. Animal health economics: an introduction. Roma: FAO.

Pitkäranta J. \& Rodenburg J., 2016. Automatic milking in large dairy herds. In: Kamphuis C. \& Steeneveld W., eds., Proceedings of the Conference on precision dairy farming, 21-23 June, 2016, Leeuwarden, The Netherlands. Wageningen, The Netherlands: Wageningen Academic Publishers, 169-173.

Porcher J. \& Schmitt T., 2010. Les vaches collaborent-elles au travail ? Une question de sociologie. Rev. Mauss, 35, 235-261.

Reichardt M. \& Jurgens E.C., 2009. Adoption and future perspective of precision farming in Germany: results of several surveys among different agricultural target groups. Precis. Agric., 10, 73-94.

Rodenburg J., 2007. Precision dairy management and the future of dairy production in Ontario. Factsheet, http://www.omafra.gov.on.ca/english/livestock/dairy/ facts/07-065.htm, (20/02/2016).

Rodenburg J., 2012. The impact of robotic milking quality, cow comfort and labor issues. In: Proceedings of the 2012 national mastitis council annual meeting, http:// www.dairylogix.com/Document-0.pdf, (16/01/2016).

Rutten C.J., Velthuis A.G.J., Steenveld W. \& Hogeveen H., 2013. Invited review: sensors to support health management on dairy farms. J. Dairy Sci., 96, 19281952.

Schewe R.L. \& Stuart D., 2015. Diversity in agricultural technology adoption: how are automatic milking systems used and to what end? Agric. Human Values, 32, 199-213.

Steeneveld W., Hogeveen H. \& Oude Lansink A.G.J.M., 2015. Economic consequences of investing in sensor systems on dairy farms. Comput. Electron. Agric., 119, 33-39.

Wathes C., 2007. Precision livestock farming for animal health, welfare and production. In: Aland A., ed. Proceedings of the $13^{\text {th }}$ International congress in animal hygiene, animal health and welfare, biosecurity, environmental protection, sustainability of animal husbandry, June 17-21, 2007, Tartu, Estonia, 397-404.

(46 ref.) 